\title{
AJOE Conference Calendar
}

October 28-31, 1999

Association For Experiential Education International Conference

Harvest The Seasons Of Learning

Rochester, NY, USA

For general information please contact $\mathrm{AEE}$ at 2305 Canyon Blvd., Suite 100, Boulder, $\mathrm{CO}$ 80302-5651. AEE's web page is www.aee.org, and it should have registration, scholarship, and service crew forms and applications up and ready as of mid-February.

\section{5 - 26 November 1999}

Asia Pacific Conference and Exhibition on Experiential Learning 1999

Venue : Apollo Hotel

Theme : "Surviving in a Knowledge

Economy : Learn, Unlearn and Relearn from Experience"

Organiser : STADA and Association for Experiential Education

http://www.stada.org.sg

29th November - 2nd December 1999 (Preconference workshops start on 27th November)

The Australian Association for Research in Education (AARE)

Global issues and local effects: The challenge for educational research

Melbourne, Australia

Visit the AARE web site:

http://www.swin.edu.au/aare if you wish to know other details.
20.-24. March 2000

Second International Adventure Therapy

Conference

Ausberg, Germany

Location: Campus University of Augsburg

Informations

c/o Michael Rehm

Kirchweg 5

D-88138 Hergensweiler

GERMANY

phone: +49 / 171/ 6829480

fax: +49 / 8388 / 980665

mailto:

michael.rehm@erlebnispaedagogik.de

http://www.erlebnispaedagogik.de/iatc

Conference

Calendar

The adjacent list

of state, national

and international

conferences and

major events is

provided as a

resource for

prospective

participants and

presenters.

Readers are encouraged to provide details of similar future events for publication in this regular feature.

\section{5-6 October, 2000}

Self-Concept Theory, Research and Practice: Advances for the New Millennium Inaugural International Conference Invitation

We extend an invitation to you to participate in the inaugural Self-concept Enhancement and Learning Facilitation (SELF) Research Centre international conference.

Further Information

Important information (e.g. call for papers, submission instructions, registration forms) on our forthcoming international conference is on our website. http://edweb.macarthur.uws.edu.au/self /

Hard Copies Conference Materials

If you require hard copies of conference information please email your postal address to Kate Johnson k.johnson@uws.edu.au.

Venue

The conference will be held in the beautiful Blue Mountains.

January 15-19, 2001

12th National Outdoor Education Conference

Melbourne - more info to follow...but put the dates aside! 